International Journal of Current Microbiology and Applied Sciences

ISSN: 2319-7706 Volume 10 Number 02 (2021)

Journal homepage: http://www.ijcmas.com

\title{
Effect of Paclobutrazol and Daminozide on Floral Attributes of Chrysanthemum (Dendranthema grandiflora Tzvelve)
}

\author{
Varun Chauhan*, Mamta Bohra, Rohan Tomar and Neha Dobhal
}

Department of Floriculture and Landscaping, College of Horticulture, VCSG, Uttarakhand University of Horticulture and Forestry, Bharsar, Pauri Garhwal-246123, India

*Corresponding author

\section{A B S T R A C T}

Keywords

Paclobutrazol, Daminozide, Dolly White

\section{Article Info}

\section{Accepted:}

20 January 2021

Available Online:

10 February 2021
The present investigation was regulate to evaluate the flowering parameters of chrysanthemum cv. Dolly White in response to different concentrations of paclobutrazol and daminozide at Floriculture and Landscaping Block, College of Horticulture, VCSG Uttarakhand University of Horticulture and Forestry, Bharsar, PauriGarwal from June to December, 2019. The experiment was located on Randomized Complete Block Design with nine treatments. The treatments used were control, paclobutazol @ (30,60, 90 and 120 ppm) and daminozide@ (250, 500, 750 and 500 ppm). Each treatment was replicated thrice. The cuttings were planted in $15 \mathrm{~cm} \times 15 \mathrm{~cm}$ (length and diameter) size pots. Paclobutrazol and daminozide were applied at 30 and 60 days after planting of cuttings. The results of experiment acknowledge that all the applied concentrations of daminozide significantly improve number of days taken to bud appearance and bud showing colour and their results were found statistically at par with each other. However, minimum days taken to full bloom (118.37 \pm 0.36 days) were observed from the plants sprayed with daminozide @ 1000 ppm and found statistically at par with daminozide @ 750 ppm (119.17 \pm 0.57 days). The maximum flower diameter $(3.54 \pm 0.05 \mathrm{~cm})$ was recorded in plants sprayed with daminozide $500 \mathrm{ppm}$ and found statistically at par with daminozide $750 \mathrm{ppm}(3.41 \pm 0.03 \mathrm{~cm})$. Maaximum number of flowers and flower longevity (20.29 \pm 0.35 and $16.78 \pm 0.58$ days, respectively) were recorded from the plants drenched with paclobutrazol @ 90 ppm. Thus, it can be revealed that highest number of flowers and flower longevity, drenching of paclbutrazol @ 90 ppm was found best. However, for getting earliness in flower bloom spray of daminozide @ 750 ppm was found useful and flower diameter was found maximum from plants sprayed with daminozide@ 500 ppm 


\section{Introduction}

Chrysanthemum is one of the beautiful oldest flowering plant, commercially grown in different parts of World (Dole and Wilkins 2005). It is a genus of approximately 30 species of perennial flowering plants which belonging to the family "Asteraceae", and found in Asia and north eastern Europe and commonly known as "Queen of East" and "AutumnQueen" (Bhattacharjee 2003). It ranks next to rose in the international flower market due to its huge range of shapes and sizes of flowers, brilliant colour tones and long lasting floret life with respect to growth habit of plant, flower shape, size and colour (Singh 2006).

Now a day growth retardants being tried for controlling growth and flowering of chrysanthemum with a view to get compact plants, to stretch-out or retard the rate of plant growth and also to delay the flowering period (Anderson 2006).Growth retardants have an inhibiting effect on cell division and enlargement of cell in plants. Paclobutrazol [(2RS, 3RS)-1-(4-chlorophenyl)-4, 4dimethyl-2-(1H-1, 2, 4-trizol-1-yl)-pentan-3$\mathrm{ol}$ ] is one of the members of triazole family having the property of growth regulating. The growth regulating properties of paclobutrazol are moderate by altering the levels of plant hormones such as gibberellins, abscisic acid (ABA) and cytokinins (Fletcher and Hofstra 1990). Daminozide inhibited gibberellin biosynthesis or action and induced flowering (Halevy, 1986). It was reported that in chrysanthemum, different photoperiods had an important role in yield and quality (Dutta et al., 1993; ByungJoo et al., 2001).

\section{Materials and Methods}

A field experiment was laid out at College of Horticulture, VCSG, UUHF, Bharsar, Pauri Garhwal, Uttarakhand, India during June-
December, 2019. The experiment consist of ten treatments viz., $\mathrm{T}_{1}$ Control(Water spray); $\mathrm{T}_{2}$ Paclobutrazol @ 30 ppm; $\mathrm{T}_{3}$ Paclobutrazol @ 60 ppm; $\mathrm{T}_{4}$ Paclobutrazol @ 90 ppm; $\mathrm{T}_{5}$ Paclobutrazol @ 120 ppm; $\mathrm{T}_{6}$ Daminozide @ $250 \mathrm{ppm} ; \mathrm{T}_{7}$ Daminozide @ $500 \mathrm{ppm} ; \mathrm{T}_{8}$ Daminozide@750 ppm; T9 Daminozide @ 1000 ppm. Paclobutrtazol was applied by soil drenching and daminozide was applied by spraying the plants. The treatments were replicated thrice in Randomized Complete Block Design. Vermicompost and farmyard manure were applied as per treatment allocation to the plots uniformly. Inorganic fertilizers were applied in the form of calcium ammonium nitrate, single super phosphate and muriate of potash. Half dose of nitrogen and full dose of phosphorous and potash was applied as a basal dose and remaining half dose of nitrogen was applied 30 days after transplanting. The terminal cuttings of chrysanthemum for experimental purpose were taken from a healthy stock plants maintained at Floriculture and Landscaping Block, Bharsar, Uttarakhand in the month of June. The length of cutting was about $5-7 \mathrm{~cm}$. Cuttings were prepared by removing basal leaves and reducing the leaf area of remaining leaves to half. The basal portion of cuttings were dipped in IBA solution @ 1000 ppm and planted in a raised nursery bed in shady conditions and then transplanted in plastic pots (length $15 \mathrm{~cm}$ and diameter $15 \mathrm{~cm}$ ) under shade condition. The pots were filled with growing media containing sand + soil + FYM + Vermicompost (1:1:1:1). In each pot a single cutting was planted at the centre. In the early morning hours Paclobutrazol and Daminozide were applied 30 and 60 days after transplanting of cuttings.

\section{Results and Discussion}

The results revealed that application of different concentrations of daminozide significantly induce earliness in flowering. 
The earliness in bud appearance $(82.48 \pm 0.45$ days) were found from the plants sprayed with $\mathrm{T}_{9}$ (daminozide @ $1000 \mathrm{ppm}$ ) and found statistically at par with $\mathrm{T}_{8}(83.45 \pm 0.39$ days $)$, $\mathrm{T}_{7}\left(83.60 \pm .25\right.$ days) and $\mathrm{T}_{6}(83.72 \pm 0.93$ days). Similarly, days taken to appearance of first flower opening were recorded in $\mathrm{T}_{9}$ (102.83 \pm 0.43 days) and found statistically at par with $\mathrm{T}_{8}$ (103.97 \pm 0.36 days), $\mathrm{T}_{7}$ (103.80 \pm .48 days $)$ and $\mathrm{T}_{6}(103.85 \pm 0.58$ days $)$. The earliness in these parameters might be due to application of daminozide reduces the indigenous level of GA to a permissible concentration required for flowering. These results were in close agreement with Dutta et al., (1993) in chrysanthemum and Kumar et al.,(2004) in balsam and Kahar (2008) in chrysanthemum. The results also revealed that minimum days taken to $50 \%$ flowering (118.37 0.36 days) were recorded from the plant sprayed with Daminozide @ 1000 ppm and found statistically at par with $\mathrm{T}_{8}(119.17 \pm$ 0.57 days). Daminozide inhibited gibberellin biosynthesis or action and induced flowering (Halevy, 1986). It could be attributed due to earliness in bud appearances causes earliness in flowering. The results are in corroborated with findings of Kazaz et al., (2010) and Asrar et al., (2014) in chrysanthemum.

All the concentrations of paclobutrazol significantly delay flowering as compared to control. The delay in flower bud appearance (89.37 \pm 0.52 days) was recorded in plants drenched with treatment $\mathrm{T}_{5}$ (paclobutrazol @ $120 \mathrm{ppm}$ ) and found statistically at par with $\mathrm{T}_{4}$ (88.64 \pm 0.77 days) and $\mathrm{T}_{3}(88.40 \pm .44$ days $)$. The maximum days taken to $50 \%$ flowering (126.62 \pm 0.78 days) was recorded from the plants sprayed with paclobutrazol @ 120 ppm and found statistically at par with $\mathrm{T}_{2}(124.74 \pm$ 0.57 days), $\mathrm{T}_{3}(126.52 \pm 0.42$ days $)$ and $\mathrm{T}_{4}$ (126.05 \pm 0.78 days). Application of paclobutrazol significantly delayed bud appearance, first flower opening and 50\% flowering might be due to the reduced GA synthesis and prolonged vegetative phase by paclobutrazol application. Delayed in flowering by the application of paclobutrazol has been reported by Gad et al., (1997) in fuschia, Gupta and Kaintura (2017) in fuschia, Foley and Keever (1991) in Dianthus spp.

The maximum flower diameter $(3.54 \pm 0.05$ $\mathrm{cm})$ was recorded in $\mathrm{T}_{7}$ and found statistically at par with $\mathrm{T}_{8}(3.41 \pm 0.03 \mathrm{~cm})$. However, minimum flower diameter $(2.50 \pm 0.02 \mathrm{~cm})$ was recorded in treatment $\mathrm{T}_{5}$ (paclobutrazol @ $120 \mathrm{ppm}$ ). The application of daminozide causes metabolic changes in the cells.

Metabolites are accumulated or conserved in the flowers as the flowers act as a reservoir for metabolites which resulted in increased flower size. Similar findings have been reported by Naidu et al., (2014) in African marigold and Asrar et al.,(2014) in chrysanthemum.

The decrease in flower diameter by the application of paclobutrazol was due to its dwarfing effect which reduces the plant height, increases the main and secondary branching there by it increase the flower number with reduction in flower diameter. Similar findings were observed by Haque et al., (2007) in Chrysanthemum cinerarifolium, Ecker (1992) in Matthiolaincana and Shailaza (2016) in chrysanthemum.

The number of flowers per plant was significantly increased by the different concentrations of daminozide and paclobutrazol. The maximum number of flowers per plant $(20.29 \pm 0.35)$ was observed in $\mathrm{T}_{4}$ paclobutrazol @ 90 ppm followed by $\mathrm{T}_{2}$ (18.41 \pm 0.53$)$ paclobutrazol @ 30 ppm. The results were corroborated with the findings of Haque et al., (2007) in Chrysanthemum cinerarifoli. Increase in number of flowers under different concentrations of daminozide might be due more plant spread has been registered under these treatment (Table 1). 
Table.1 Effect of different concentrations of paclobutrazol and daminozide on floral attributes of chrysanthemum cv. Dolly White

\begin{tabular}{|c|c|c|c|c|c|c|}
\hline Treatments & $\begin{array}{l}\text { Bud appearance } \\
\text { (days) } \pm \text { S.E(m) }\end{array}$ & $\begin{array}{c}\text { First flower } \\
\text { opening (days) } \\
\pm \text { S.E(m) }\end{array}$ & $\begin{array}{c}50 \% \text { flowering } \\
\text { (days) } \pm \\
\text { S.E(m) }\end{array}$ & $\begin{array}{c}\text { Flower } \\
\text { diameter }(\mathbf{c m}) \\
\pm \text { S.E }(\mathbf{m}) \\
\end{array}$ & $\begin{array}{c}\text { Number of } \\
\text { flowers per } \\
\text { plant } \pm \text { S.E(m) }\end{array}$ & $\begin{array}{c}\text { Flower longevity } \\
\text { (days) } \pm \\
\text { S.E(mm) }\end{array}$ \\
\hline $\mathbf{T}_{1}$ (Control) & $85.66 \pm 0.29$ & $105.73 \pm 0.68$ & $122.23 \pm 0.31$ & $3.02 \pm 0.10$ & $14.16 \pm 0.38$ & $11.25 \pm 0.51$ \\
\hline $\begin{array}{c}\mathbf{T}_{2} \text { (Paclobutrazol @ } 30 \\
\text { ppm) }\end{array}$ & $87.52 * \pm 0.60$ & $108.52 * \pm 0.57$ & $124.74 * \pm 0.57$ & $2.84 * \pm 0.06$ & $18.41 * \pm 0.53$ & $14.73 * \pm 0.60$ \\
\hline $\begin{array}{c}T_{3} \text { (Paclobutrazol @ } 60 \\
\text { ppm) }\end{array}$ & $88.40 * \pm 0.44$ & $109.15 * \pm 0.48$ & $126.52 * \pm 0.42$ & $2.82 * \pm 0.03$ & $17.32 * \pm 0.86$ & $14.52 * \pm 0.63$ \\
\hline $\begin{array}{c}\mathbf{T}_{4} \text { (Paclobutrazol @ } 90 \\
\text { ppm })\end{array}$ & $88.64 * \pm 0.77$ & $109.39 * \pm 0.62$ & $126.05 * \pm 0.78$ & $2.69 * \pm 0.06$ & $20.29 * \pm 0.35$ & $16.78 * \pm 0.58$ \\
\hline $\begin{array}{c}\mathbf{T}_{5} \text { (Paclobutrazol@120 } \\
\text { ppm) }\end{array}$ & $89.37 * \pm 0.52$ & $109.68 * \pm 0.72$ & $126.62 * \pm 0.16$ & $2.50 * \pm 0.02$ & $16.41 * \pm 0.41$ & $13.40 * \pm 0.95$ \\
\hline $\mathbf{T}_{6}$ (Daminozide @ 250 ppm) & $83.72 * \pm 0.93$ & $103.85^{*} \pm 0.58$ & $120.11 * \pm 0.33$ & $3.15 \pm 0.11$ & $18.12 * \pm 0.76$ & $14.60 * \pm 0.35$ \\
\hline $\mathbf{T}_{7}$ (Daminozide @ 500 ppm) & $83.60 * \pm 0.25$ & $103.80 * \pm 0.48$ & $120.28 * \pm 0.56$ & $3.54 * \pm 0.05$ & $16.69 * \pm 0.62$ & $13.53 * \pm 0.42$ \\
\hline $\mathbf{T}_{8}$ (Daminozide@ 750 ppm) & $83.45 * \pm 0.39$ & $103.97 * \pm 0.36$ & $119.17 * \pm 0.57$ & $3.41 * \pm 0.03$ & $16.18^{*} \pm 0.36$ & $13.29 * \pm 0.39$ \\
\hline $\begin{array}{c}\text { T9 (Daminozide @ } 1000 \\
\text { ppm) }\end{array}$ & $82.48 * \pm 0.45$ & $102.83 * \pm 0.43$ & $118.37 * \pm 0.36$ & $3.27 * \pm 0.09$ & $15.84 \pm 0.51$ & $12.98 * \pm 0.49$ \\
\hline S.E. (d) & 0.81 & 0.72 & 0.67 & 0.06 & 0.83 & 0.79 \\
\hline C.D. $(0.05)$ & 1.74 & 1.55 & 1.43 & 0.14 & 1.78 & 1.70 \\
\hline
\end{tabular}

*significant at 0.05 level of significance 
Similar results were also reported by Singh (2001) in chrysanthemum, Maan (2003) in marigold and Subramanian and Kannapan (2002) in Jasminum sambac.

Maximum flower longevity was recorded from the plants drenched withstand $\mathrm{T}_{4}(16.78$ \pm 0.58 days $)$ followed by $\mathrm{T}_{2}(14.73 \pm 0.60$ days) and $\mathrm{T}_{6} \quad(14.60 \pm 0.35$ days $)$. Paclobutrazol influences the isoprenoid pathway and changes the status of phytohormones by inhibiting gibberellin synthesis, decreasing ethylene production, and enhancing cytokinin and ABA contents (Kamountsis and Sereli, 1999).

The increase in flower longevity with spraying of daminozide are in close conformity with the findings of Asrar et al., (2014) who also reported increased flower longevity and duration with increasing concentration of daminozide.

The results revealed that for getting earliness in flower bloom all the applied concentration of daminozide was found significantly effective whereas all the applied concentration of paclobutrazol was found effective in delaying flowering as compared to control. Flower diameter was found maximum in plants sprayed with daminozide @ 500 ppm and found statistically at par with daminozide @ $750 \mathrm{ppm}$. Flower longevity was recorded maximum in daminozide @ 1000 ppm and found statistically at par with paclobutrazol @ 90 ppm and daminozide @ 750 ppm.

Therefore, from the above findings it can be concluded that to get maximum plant spread, number of flowers and flower longevity drenching of paclobutrazol @ 90 ppm can be recommended. Spraying of daminozide @ 750 ppm was found effective in inducing earliness in full bloom and flower diameter was found maximum from plants spread with daminozide @ 500 ppm.

\section{References}

Anderson N.O. 2006. Chrysanthemums, Dendranthema $x$ grandiflora Tzvelv. In Anderson, N. (ed.). Flower Breeding and Genetics. Springer, Dordrecht, pp. 389-37.

Asrar, A. W., Elhindi, K. and Salam, E. A. 2014. Growth and flowering response of chrysanthemum cultivars to Alar and slow-release fertilizer in an outdoor environment. Journal of Food Agriculture and Environment. 12(2): 963-71.

Bhattacharjee, S. K. 2003. Advances in ornamental horticulture. Pointer Publishers, Jaipur, India. 35p.

ByungJoo L., MiKyoung W., DongHee L. and DongGi S. 2001. Flowering responses to sequental short day/long day exposure in chrysanthemum (Dendranthema grandiflora 'Tzvelev'). Korean J. Hort. Sci. Tech., 19(4): 560563.

Dole J.M. and Wilkins H.F. 2005. Floriculture principles and species. Prentice- Hall, Inc, USA. pp. 1023.

Dutta, J. P., Seemanthini, R., Khader, M. A. and Ramdas, S. 1993. Regulation of flowering by growth regulators in chrysanthemum (Chrysanthemum indicum L.) cv. Co-1. South Indian Horiculture. 41(5): 293-295.

Ecker, R. A., Barzilay, L. Afgin, A. and Watad A. 1992. Growth and flowering responses of Mathiolaincana to paclobutrazol. HortScience. 27(12): 1330.

Fletcher, R.A. and Hofstra, G. 1990. Improvement of uniconazole induced protection in wheat seedlings. Journal of Plant Growth Regulation, 9, 207212.

Foley, T., and Keever, G. K. 1991. Growth regulators and pruning alter growth and axillary shoot development of 
Dianthus. Journal of Environmental Horticulture. 9: 191-195.

Gad, M., Schmidit, G. and Gerzson, L. 1997. Comparision of application methods of growth retardants on the growth and flowering of Fuchsia magellanicaLam. Horticultural Science. 21(2): 263-64.

Gupta, Y. and Kaintura, P. 2017. Response of paclobutrazol as spray and drench on pot grown fuchsia cv. Pink Galore. Journal of Plant Science Research. 2(1): 13-17.

Halevy, A. H. 1986. Recent advances in the use of growth substances in ornamental horticulture. Heidelberg, Berlin, West Germany, 391- 398p.

Haque, S., Farooqi, A. H. A., Gupta, M. M., Sangwan, R. S. and Khan, A. 2007. Effect of ethrel, chlormequat chloride and paclobutrazol on growth and pyrethrins accumulation in Chrysanthemum cinerariaefolium. Plant Growth Regulators. 51: 263-69.

Kahar, S. A. 2008. Effects of frequency and concentration of B-9 (daminozide) on growth, flowering and flower quality of Reagan Sunny chrysanthemum Chrysanthemum morifolium Ramat. Acta Horticulturae. 4: 788-87.

Kamountsis, A. P., and Sereli, C. 1999. Paclobutrazol affects growth and flower bud production in gardenia under different light regimes. Horticultural Science. 34: 674-675.

Kazaz, S., Askin, M. A., Kilic, S. and Ersoy, N. 2010. Effects of day length and daminozide on the flowering, some quality parameters and chlorophyll content of Chrysanthemum morifolium Ramat. Scientific Research and Essays. 5(21): 3281-88.

Kumar, S., Kumar, M., Rana, P. and Kumar J. 2004. Effect of maleic hydrazide on growth and flowering of balsam (Impatiens balsamina L.). Journal of Farming Systems Research and Development. 10(1-2): 121-122.

Maan, V. 2003. Influence of paclobutrazol on growth and flowering of African marigold (Tagetes erecta $\mathrm{L}$.) cv. Pusa Narangi Gainda. M.sc. (Agri). Thesis submitted to Gujarat Agricultural University, Gujarat.

Naidu, J. H., Ashok, P., Shekhar, R. C., Sasikala, K. 2014. Effect of plant growth retardants and spacings on vegetative growth and flower yield of African marigold (Tageteserecta $\mathrm{L}$ ) cv. Pusa Narangi Gainda. International Journal of Farm Sciences. 4(2): 92-99.

Shailaza B. 2016. Growth and floral characters of chrysanthemum potmums (Dendranthema grandiflora). M.Sc. thesis submitted to Dr. Yashwant Singh Parmar University of Horticulture and Forestry, Solan.

Singh A.K. 2006. Flower Crops Cultivation and Management. Pp 73-83. New India Publishing, Delhi, India.

Singh, J. 2001. Effect of plant growth substances on growth flowering and yield of chrysanthemum (Chrysanthemum coronarium) cv. Local White. M.Sc. (Agri.) Thesis submitted to Gujarat Agricultural University, Gujarat.

\section{How to cite this article:}

Varun Chauhan, Mamta Bohra, Rohan Tomar and Neha Dobhal. 2021. Effect of Paclobutrazol and Daminozide on Floral Attributes of Chrysanthemum (Dendranthema grandiflora Tzvelve). Int.J.Curr.Microbiol.App.Sci. 10(02): 2754-2759. doi: https://doi.org/10.20546/ijcmas.2021.1002.304 